\title{
CURCUMIN BENEFITS AS ANTIOXIDANT, ANTIINFLAMATION AND ANTIAPOPTOSIS AMELIORATE PARACETAMOL TOXICITY
}

\author{
TEJO JAYADI ${ }^{1 *}$, BOWO WIDIASMOKO ${ }^{2}$
}

${ }^{1}$ Department of Anatomical Pathology, Faculty of Medicine, Duta Wacana Christian University, Yogyakarta, Indonesia, ${ }^{2}$ Department of Internal Medicine Bethesda Hospital Yogyakarta, Yogyakarta, Indonesia. Email: tejo_jayadi@staff.ukdw.ac.id

Received: 07 December 2017, Revised and Accepted: 28 August 2018

\section{ABSTRACT}

Background: Paracetamol poisoning due to the use of paracetamol overdose is the most prevalent case of poisoning. Toxic metabolites from paracetamol cause glutathione depletion and lead to hepatic cell death. Curcumin, a polyphenol substrat in Curcuma longa, has been known to ameliorate the toxic effects of paracetamol. The mechanisms have been known are curcumin as antioxidant, anti-inflammatory, and anti-apoptotic. The curcumin protection mechanism against paracetamol poisoning will be discussed.

Methods: The journal's search for the protective effects of curcumin on paracetamol toxicity is derived from PubMed database using keyword curcumin and acetaminophen. Research on experimental animals is as the limits of the study subjects of the journal search.

Result: From a search in PubMed database, there are 15 journal titles discussing the effects of curcumin protection against paracetamol toxicity, and 11 journals selected that correspond to the research topic. Of the 11 journals selected, concluded that curcumin was found to prevent worsening of paracetamol toxicity by increasing antioxidant activity and decreasing inflammation and apoptotic.

Conclusion: Curcumin has the potential benefit to be used as a medical therapeutic for the prevention and treatment of paracetamol toxicity.

Keywords: Curcumin, Paracetamol, Antioxidants, Anti-inflammatory, Anti-apoptotic.

(C) 2018 The Authors. Published by Innovare Academic Sciences Pvt Ltd. This is an open access article under the CC BY license (http://creativecommons. org/licenses/by/4. 0/) DOI: http://dx.doi.org/10.22159/ajpcr.2018.v11s3.29959

\section{BACKGROUND}

Paracetamol or acetaminophen is also known as $\mathrm{N}$-acetyl p-aminophenol has been used as an antipyretic and analgesic for more than 30 years. Paracetamol poisoning is the largest poisoning case according to the American Association of Poison Control Centers causes 140,000 cases of poisoning and approximately 100 mortalities in the year 2006 [1]. At therapeutic dose, paracetamol will be metabolized in the liver through a process of glucuronidation and sulfation and excreted from the cell, a small part will be metabolized by Cytochrome P450 especially CYP2E1 to N-acetyl-p-benzoquinoneimine (NAPQI) toxic product. NAPQI will be rapidly detoxified by glutathione (GSH) and removed from the cell. An overdose of paracetamol may cause hepatic dysfunction, necrosis of hepatic cells, and hepatic organ injury [2]. GSH depletion due to the NAPQI detoxification process will occur rapidly [2-4], so that the free NAPQI will bind to intracellular proteins and lipids as well as intranuclear deoxyribonuclease acid, through covalent bonding, causing mitochondrial dysfunction, lipid peroxidation, oxidative stress, DNA fragmentation, leading to liver cell death, liver organ damage, and ending with death $[2,3]$.

$\mathrm{N}$-acetyl cysteine has been used as a paracetamol poisoning antidote, has a narrow therapeutic dose range and side effects, so an alternative therapeutic need is sought. Curcumin ((1E, 6E) -1,7-bis- (4-hydroxy-3methoxyphenyl) -1,6-heptadien-3,5-dione), a polyphenol presents in the roots of the Curcuma longa plant has been used as a treatment traditional for liver disorders that are now known to be caused by oxidative stress. Curcumin has properties as antioxidants, anti-inflammatory, and antiapoptosis that can improve the toxic effects of paracetamol overdose. This is interesting to discuss further. The review paper will gather several journals to discuss curcumin protection mechanisms in improving paracetamol toxicity.

\section{RESEARCH METHODS}

Journal searches on the benefits of curcumin as an antioxidant and anti-inflammatory to reduce the toxic effects of paracetamol derived from the PubMed database using curcumin and acetaminophen as the keywords, no years of limitation, and research on experimental animals as the limits of the study subjects.

\section{RESULTS}

Journals search in PubMed database was obtained 15 journal titles, and there are 11 journals that discuss the protective effect of curcumin against paracetamol toxicity, obtained five journals that could be accessed fully, and six journals only the abstract could be accessed. All the journals that could be fully access and one of the journal abstracts will be summarized in Table 1 .

\section{DISCUSSION}

\section{The role of NAPQI in cellular damage}

Reactive N-acetyl-p-benzoquinone imine (NAPQI) metabolites of paracetamol oxidation by CYP2E1 bind to the cysteine group of proteins; forming acetaminophen-protein adducts [7]. Most of the paracetamolreactive metabolites bind through NAPQI reactions with cysteinyl sulfhydryl (-SH) groups proteins to produce 3- (cysteine-S-yl) APAP (3-Cys-A) -protein adduct, or (APAP-CYS) acetaminophen- cysteine in hepatocytes. APAP-CYS adducts are detected in mitochondria, plasma membranes, and hepatocyte cytosol [8].

NAPQI covalent binding to mitochondrial membrane proteins will inhibit mitochondrial respiration and decrease oxygen consumption trough slowing the activities of succinate dehydrogenase (respiration complex II) and NADPH dehydrogenase (respiration complex I). The decrease of oxygen consumption causes decrease in ATP production, ultimately causing cell necrosis. NAPQI covalent binding also open the mitochondrial transition pore (MTP). NAPQI in the mitochondrial increases the production of reactive oxygen species (ROS) and reactive nitrogen species (RNS) causing oxidative stress. Oxidative stress damages the regulation of cytosol calcium and mitochondrial calcium 
Table 1: Several curcumin protection effects research on paracetamol toxicity

\begin{tabular}{|c|c|c|}
\hline Author & Method & Result \\
\hline $\begin{array}{l}\text { Bulku et al., 2012[5] } \\
\text { Abstract }\end{array}$ & Research on four groups of male B6C3F1 mice & $\begin{array}{l}\text { Administration of curcumin: Mortality decreased; } \\
\text { decrease of ALT serum, lipid peroxidation, and DNA } \\
\text { fragmentation; increase of GSH, SOD, NO synthase, } \\
\text { decrease of DNA fragmentation, Bax gene expression, } \\
\text { caspase 3, cytochrome c, and p53; and increase of } \\
\text { Bcl-XL }\end{array}$ \\
\hline Somanawat et al., 2013 [2] & Research on four groups of male mice & $\begin{array}{l}\text { Administration of curcumin: Decrease of AST and } \\
\text { ALT serum, hepatic MDA, IL-12 and IL-18 serum; and } \\
\text { increase of hepatic GSH }\end{array}$ \\
\hline Li et al., 2013 [3] & Research on three groups of Balb-c male mice & $\begin{array}{l}\text { Administration of curcumin: Reduce hepatic histologic } \\
\text { damage; decreases of ALT serum and hepatic MDA; } \\
\text { increases of hepatic SOD, hepatic Bax gene expression; } \\
\text { increases of hepatic Bcl- } 2 \text { gene expression; and } \\
\text { prevent hepatic apoptosis }\end{array}$ \\
\hline Soliman et al., 2014 [4] & Research on four groups of male rats Wistar strain & $\begin{array}{l}\text { Administration of curcumin: Amelioratif hepatic } \\
\text { histologic; decreace of ALT, AST, and urea serum; } \\
\text { increased level of hepatic catalase antioxidants; } \\
\text { decreased of hepatic MDA, hepatic MMP-8 expression } \\
\text { in ihc imaging, increase of hepatic hepatic GSH, GPx, } \\
\text { SOD, and catalase gene expression; and decrease of } \\
\text { hepatic IL-1 } \beta \text {, IL-8, and TNF } \alpha \text { gene expression }\end{array}$ \\
\hline Granados-Castro et al., 2016 [1] & Research on six groups of male CD1 mice & $\begin{array}{l}\text { Administration of curcumin protecting hepatic } \\
\text { histologic damage; decrease of ALT and AST; prevent } \\
\text { decrease in mitochondrial activity of respiratory } \\
\text { complex I, III, and IV; and prevent decrease in } \\
\text { mitochondrial membrane potential, ATP synthesis, } \\
\text { and aconitase activity }\end{array}$ \\
\hline Kheradpezhouh et al., 2016 [6] & Research on Wistar mouse hepatocyte culture & $\begin{array}{l}\text { Administration of curcumin inhibits TRPM } 2 \text { channel } \\
\text { activation Bay ADPR }\end{array}$ \\
\hline
\end{tabular}

ALT: Alanine aminotransferase, AST: Aspartate aminotransferase, MMP: Mitochondrial membrane potential, GSH: Glutathione; SOD: Superoxide dismutase, NO: Nitric oxide, MDA: Malondialdehyde, IL-12, IL-18, IL-8: Interleukin, MMP-8: Matrix metalloproteinase-8, TRPM2: Transient receptor potential melastatin 2, ADPR: Adenosine diphosphate ribose, TNF- $\alpha$ : Tumor necrosis factor- $\alpha$

and opens the MTP. Changes in mitochondrial membranes cause translocation of the B-cell lymphoma-2 (Bcl-2)-associated-X (Bax) protein, which combines with Bcl-2 antagonist killer 1 (Bak) into the cytosol, and allow the release of intermembrane proteins such as cytochrome c, regulates cellular death programs (apoptosis), through nuclear DNA fragmentation, and p53 pathway. ROS and RNS oxidized thiols groups (structural component of MTP, causing mitochondrial potential membrane damage, then swelling and rupture of the outer membrane of mitochondria [3]).

NAPQI in the cytosol will deplete GSH, resulting in increased intracellular ROS production. ROS will be neutralized by catalase, superoxide dismutase (SOD), glutathione-S transferase (GST), and glutathione peroxidase (GPx) causing the decline of these intracellular antioxidants. ROS will activate transient receptor potential melastatin 2 (TRPM2), a nonselective $\mathrm{Ca}^{+2}$ permeable cation channels through intracellular adenosine diphosphate ribose (ADPR), allowing extracellular calcium to enter intracellularly, causing increase of intracellular calcium, and inducing further transition of membrane mitochondrial [6].

\section{The role of inflammation in cellular damage}

Macrophages havean important direct role in the early stage of paracetamolinduced hepatic management [9]. When activated hepatic macrophages are cells Kupffer release several molecules, i.e. hydrolytic enzymes, eicosanoids, nitric oxide, and superoxide. It also releases inflammatory cytokines, interleukin (IL)-1, IL-6, and tumor necrosis factor- $\alpha$ (TNF- $\alpha$ ) [7]. Some inflammatory cytokines also increase in IL-12, IL-18 [2], IL-1 $\beta$, and IL-8 regulated by matrix metalloproteinase 8 (MMP-8) [4].

\section{Curcumin protecting toxic effects of paracetamol toxicity}

Curcumin is known as antioxidant, anti-inflammatory, and antiapoptosis. As the antioxidant, curcumin binds directly to the toxic metabolite of paracetamol and decreases the use of GSH [10], and also neutralizes and scavengering the oxidant ROS and RNS. Indirectly, through the activation of nuclear factor (erythroid-derived-2)- like2 (Nrf2) transcription factor by curcumin, the production of catalase, SOD, GST, and GPx in nucleus increase and release into cytosol (Granados-Castro et al., 2016) [1]. The increased level of GST stimulates GSH formation which increases the excretion of the paracetamol toxic metabolites [10]. If the free radicals are reduced, mitochondrial membrane damage and DNA fragmentation will also decrease, thus inhibiting the production of ADPR. Curcumin inhibits ADPR -mediated TRPM2 activation, thus preventing further calcium influx and kalium efflux. Preventing further intracellular calcium accumulation will prevent cell damage [6]. The decrease in free radical and the binding of NAPQI by curcumin, protecting lipid peroxidation and can be demonstrated by the reduction of malondialdehyde free radicals. The increase of antioxidant levels by curcumin can be demonstrated by an increased expression of GSH mRNA, GPx mRNA, SOD mRNA, and catalase mRNA [4].

Curcumin enhances PPAR $\alpha$ expression, known to play a major role in the immune response because it can prevent the production of inflammatory substances [11,12]. Curcumin given along with paracetamol decreases the expression of IL $1 \beta$, TNF- $\alpha$, and IL- 8 genes, expression of the $\alpha 1$-acid glycoprotein gene, enhancing the expression of the macroglobulin $\alpha-2$ gene, and decreasing MMP-8 expression [4]. Curcumin also reduces serum level of IL-12 and IL-18 [2].

Curcumin decreases the expression of mRNA Bax and increases the expression of mRNA Bcl-2, thereby decreasing apoptosis induced by paracetamol. Bcl-2 protein is an anti-apoptosis factor, its activity prevents mitochondrial membrane disruption, Bax will inactivate Bcl-2 through the formation of heterodimer [3]. 


\section{CONCLUSION}

The toxic effects of paracetamol overdose are better understood now. Oxidative stress mechanisms and NAPQI covalent bonds with intracytosol and intramycrosome proteins play an important role. Curcumin has antioxidant and anti-inflammatory activity, is expected to be one of the natural ingredients selected for the prevention of paracetamol toxicity in patients receiving long-term and high-dose paracetamol therapy.

\section{REFERENCES}

1. Granados-Castro LF, Rodríguez-Rangel DS, Fernández-Rojas B, León-Contreras JC, Hernández-Pando R, Medina-Campos ON, et al. Curcumin prevents paracetamol-induced liver mitochondrial alterations. J Pharm Pharmacol 2016;68:245-56.

2. Somanawat K, Thong-Ngam D, Klaikeaw N. Curcumin attenuated paracetamol overdose induced hepatitis. World J Gastroenterol 2013;19:1962-7.

3. Li G, Chen JB, Wang C, Xu Z, Nie H, Qin XY, et al. Curcumin protects against acetaminophen-induced apoptosis in hepatic injury. World $\mathrm{J}$ Gastroenterol 2013;19:7440-6

4. Soliman MM, Abdo Nassan M, Ismail TA. Immunohistochemical and molecular study on the protective effect of curcumin against hepatic toxicity induced by paracetamol in wistar rats. BMC Complement
Altern Med 2014;14:457.

5. Bulku E, Stohs SJ, Cicero L, Brooks T, Halley H, Ray SD, et al. Curcumin exposure modulates multiple pro-apoptotic and antiapoptotic signaling pathways to antagonize acetaminophen-induced toxicity. Curr Neurovasc Res 2012;9:58-71

6. Kheradpezhouh E, Barritt GJ, Rychkov GY. Curcumin inhibits activation of TRPM2 channels in rat hepatocytes. Redox Biol 2016;7:1-7.

7. James LP, Mayeux PR, Hinson JA. Acetaminophen-induced hepatotoxicity. Drug Metab Dispos 2003;31:1499-506.

8. Heard KJ, Green JL, James LP, Judge BS, Zolot L, Rhyee S, et al. Acetaminophen-cysteine adducts during therapeutic dosing and following overdose. BMC Gastroenterol 2011;11:20.

9. Goldin RD, Ratnayaka ID, Breach CS, Brown IN, Wickramasinghe SN. Role of macrophages in acetaminophen (paracetamol)-induced hepatotoxicity. J Pathol 1996;179:432-5.

10. Khorsandi L, Orazizadeh M. Protective effect of Curcuma longa extract on acetaminophen induced nephrotoxicity in mice. DARU 2008;16:155-9.

11. Rivera P, Pastor A, Arrabal S, Decara J, Vargas A, Sánchez-Marín L, et al. Acetaminophen-induced liver injury alters the acyl ethanolaminebased anti-inflammatory signaling system in liver. Front Pharmacol 2017;8:705.

12. Mazidi M, Karimi E, Meydani M, Ghayour-Mobarhan M, Ferns GA. Potential effects of curcumin on peroxisome proliferator-activated receptor- $\gamma$ in vitro and in vivo. World J Methodol 2016;6:112-7. 